\title{
Implementasi Fungsi Planning di Sekolah Dalam Kerangka Manajemen Pendidikan Islam
}

\author{
Ahmad Ridwan \\ PPS Prodi MPI Universitas Islam Negeri Sulthan Thaha Saifuddin Jambi \\ ahmadridwan1474@gmail.com
}

\begin{abstract}
Abstrak
Fungsi planning dalam manajemen pendidikan Islam merupakan sebuah strategi yang dapat diwujudkan dalam sebuah keputusan dan tindakan yang dilakukan selama waktu tertentu sesuai dengan jangka waktu perencanaan agar penyelenggaraan sistem pendidikan menjadi lebih efektif dan efesien serta menghasilkan lulusan lembaga pendidikan yang bermutu dan relevan dengan kebutuhan masyarakat. Sebagai upaya peningkatkan efektifitas dan efeisensi kerja suatu organisasi pendidikan perhitungan-perhitungan secara teliti sudah harus dilakukan pada fase perencanaan pendidikan dan memfungsikannya secara optimal. Untuk itu dalam proses merencanakan perencanaan pendidikan prinsip-prinsip perencanaan harus mencerminkan nilai-nilai kebaikan dan rasa tanggung jawab bagin setiap individu dalam lembaga pendidikan. Sangat diperlukannya upaya penyadaran, serta pembinaan oleh kepala sekolah akan pentingnya implementasi sistem planning dalam manajemen sekolah dengan melibatkan guru dan sumber daya sekolah yang ada secara langsung terutama dalam proses kegiatan perencanaan sekolah.

Kata Kunci: Fungsi Palnning, Manajemen Pendidikan Islam, Efentifitas dan Efisiensi.
\end{abstract}

\section{PENDAHULUAN}

Perencanaan pendidikan merupakan suatu yang penting dalam mempertahankan sebuah lembaga pendidikan. Perencanaan sebagai alat bantu para pengelola pendidikan untuk menjadi lebih berdaya guna dalam melaksanakan tugas dan fungsinya. Perencanaan dapat menolong pencapaian suatu target atau sasaran lebih ekonomis, tepat waktu dan memberi peluang untuk mudah dikontrol dan dimonitor dalam pelaksanannya. Karena itu perencanaan sebagai unsur dan langkah pertama dalam fungsi pengelolaan pada umumnya menempati posisi yang sangat penting dan amat menentukan.

Ada pun landasan dasar perencanaan pendidikan adalah kemampuan manusia untuk secara sadar memilih alternatif masa depan yang dikehendakinya dan kemudian mengarahkan daya upayanya untuk mewujudkan masa depan yang dipilihnya. Dalam hal ini manajemen yang seperti apa yang akan diterapkan, sehingga suatu rencana yang diharapkan tersebut akan terelealisasi dengan baik.

Oleh sebab itu dalam upaya meningkatkan efektifitas dan efeisensi suatu organisasi pendidikan perhitunganperhitungan secara teliti sudah harus dilakukan pada vase perencanaan pendidikan. Untuk itu dalam proses merencanakan perencanaan pendidikan prinsip-prinsip perencanaan harus mencerminkan nilai-nilai kebaikan dan rasa tanggung jawab. Hal ini sejalan dengan firman Allah sebagai berikut:

$$
\begin{aligned}
& \text { ولاتقف ماليس لك به علم ان السمع والبصروالفوءادكل }
\end{aligned}
$$

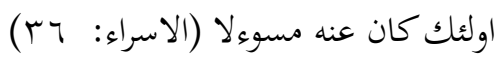

Artinya: Dan janganlah kamu mengikuti apa yang kamu tidak mempunyai pengetahuan tentangnya. Sesungguhnya pendengaran, penglihatan dan hati, 
semuanya itu akan diminta pertanggungan jawabnya.(QS.Al-Isra: 17:36). ${ }^{1}$

Secara eksplisit ayat di atas menjelaskan bahwa sesuatu hal yang prinsip dalam sebuah perencanaan adalah menjalankan perencanaan itu dengan jalan yang baik, dan penuh dengan rasa tanggung jawab, tanggung jawab kemanusiaan, dan tanggung kehidupan manusia terhadap Tuhannya serta bukan hanya dipandang sebagai spekulasi semata, yang dapat dilakukan tanpa ada pertimbangan, agar tujuan yang ingin dicapai dalam perencanaan tersebut dapat terwujud dengan sempurna.

Upaya-upaya untuk meningkatkan kinerja guru biasnya dengan cara memberikan motivasi dan perencanaan manajemen tenaga kependidikan. perencanaan manajemen pendidikan dan kependidikan merupakan langkah yang strategis dalam pengembangan dan strategi penyusunan sumber daya manusia yang komperhensif guna memenuhi kebutuhan organisasi di masa depan. Perencanaan SDM ini merupakan hal yang sangat penting dan langkah awal dari pelaksanaan fungsi manajemen SDM namun demikian perencanaan ini seringkali diabaikan padahal dengan perencanaan atau implementasi fungsi planning ini segala fungsi guru sebagai sumber daya manusia dapat dilaksanakan secara efektif.

Untuk itu diperlukan sebuah upaya penyadaran, serta pembinaan terhadap kepala sekolah akan pentingnya implementasi sistem planning dalam manajemen sekolah seperti dengan

1 Departemen Agama, Al-Qur'an dan Terjemah, (Bandung: CV Diponegoro, 2007), hal. 498

2 Hikmat, Manajemen Pendidikan, (Bandung: Pustaka setia Bandung, 2011), hal. 101 membimbing dan melibatkan guru secara langsung dalam proses kegiatan perencanaan sekolah.

\section{Konsep Planning (Perencanaan) Dalam Sistem Pendidikan Islam}

Planning berasal dari bahasa Inggris "plan" rtinya rencana, rancangan, maksud, atau niat. Planning berarti perencanaan. Dan "education" artinya pendidikan. Jadi pengertian perencanaan pendidikan adalah proses kegiatan pendidikan. Sedangkan rencana pendidikan adalah hasil perencanaan yang telah dirumuskan dan ditetapkan bersama. $^{2}$ Perencanaan merupakan keseluruhan proses pemikiran dan penentuan secara matang hal-hal yang akan dikerjakan pada masa yang akan datang untuk pencapaian tujuan yang telah dilakukan. Para ahli berbeda pendapat dalam mendefinisikan perencanaan pendidikan antara lain dapat diuraikan sebagai berikut:

Albert Waterson dalam Udin Syaefudin Saud dan Abin Syamsudin Makmun menyatakan bahwa :

"Functional planning involves the aplication for a rational system of choices emong feasibel courses of educational investment and the other development actions based on consideration of economic and social cost and benefits". 3

Secara bebas dapat diterjemahkan sebagai berikut: Enoch sebagaimana dikutip Syaiful Sagala mendefinisikan perencanaan pendidikan sebagai "suatu proses mempersipakan alternatif keputusan bagi kegiatan masa depan yang diarahkan kepada pencapaian tujuan dengan usaha yang optimal, mempertimbangkan kenyataan-kenyataan dibidang ekonomi,

\footnotetext{
${ }^{3}$ Udin Syaefudin Saud dan Abin Syamsudin Makmun, Perencanaan Pendidikan Suatu Pendekatan Komperehendif, (Bandung: PT Rosda Karya, 2005), hal. 8
} 
sosial, budaya, secara menyeluruh dari suatu negara". ${ }^{4}$

Sedangkan Fattah sebagaimana dikutip M. Daryanto mengemukakan bahwa perencanaan pendidikan adalah keputusan yang dilakukan untuk melakukan tindakan selama waktu tertentu sesuai dengan jangka waktu perencanaan agar penyelenggaraan sistem pendidikan menjadi lebih efektif dan efesien serta menghasilkan lulusan yang bermutu dan relevan dengan kebutuhan masyarakat. $^{5}$

Berdasarkan beberapa definisi di atas dapat dipahami bahwa perencanaan pendidikan pada dasarnya adalah proses pengambilan keputusan untuk mempersiapakan kegiatan di masa mendatang dengan berbagai perimbangan ekonomi, sosial, dalam rangka mencapai tujuan pendidikan yang efektif dan efesien.

Udin Syaefudin Saud dan Abin Syamsudin Makmun membagi empat unsur perencanaan antara lain:

a. Penggunaan analisis yang bersifat rasional dan sistematik.

Hal ini menyangkut metodologi perencanaan pendidikan yang meliputi "pendekatan sosial, Man Power, Cost Benefit, Strategic, dan Comprehensif"

b. Proses pengembangan pembangunan pendidikan

Artinya, bahwa perencanaan pendidikan dilakukan dalam rangka reformasi pendidikan yaitu suatu proses dari status sekarang menuju ke status perkembangan pendidikan yang dicitacitakan .

c. Prinsip efektifitas dan efesien

d. Kebutuhan dan tujuan peserta didik masyarakat (lokal, regional, nasional dan internasional). Artinya perencanaan pendidikan itu mencakup aspek internal

${ }^{4}$ Syaiful Sagala, Kemampuan Profesional Guru dan Tenaga Kependidikan, (Banung: Alfa Beta, 2011), hal. 54

${ }^{5}$ M. Daryanto, Administrasi dan Manajemen Sekolah, (Jakarta: Rineka Cipta), 2012, hal. 85

${ }^{6}$ Loc. Cit, hal. 9 dan eksternal dari keorganisasian itu sendiri. ${ }^{6}$

Sedangkan menurut Didin Kurniadin dan Imam Machali unsur -unsur perencanaan pendidikan antara lain:

a. Menggunakan analisis yang bersifat rasional dan sistemik.

b. Terkait dengan pembangunan dan dilakukan dalam rangka reformasi pendidikan.

c. Kegiatan yang kontinu.

d. Mencakup aspek internal dan eksternal.

e. Mempertimbangkan prinsip efektifitas dan efesien. ${ }^{7}$

Adanya perbedaan pandangan tentang unsur-unsur di atas menunjukkan bahwa kompleksnya persoalan perencanaan pendidikan. dengan kata lain perencanaan pendidikan merupakan hal yang amat penting karena perencanaan pendidikan akan berkaitan dengan fasilitas, sarana dan prasarana, yang telah dimiliki atau yang belum dimiliki sehingga perencaan pendidikan yang tidak proporsional akan mempersulit terlaksananya kegiatan pendidikan dengan cara yang efektif dan efesien. Untuk itu diperlukan upaya pertimbangan yang matang.

Kemudian dengan pertimbanganpertimbangan tersebut Sefullah merumuskan perencanaan melalui fase-fase yang sistemis yaitu:

a. Menyusun tujuan-tujuan mulai dari yang umum hingga yang khusus

b. Menyusun rencana sesuai dengan tujuan

c. Melaksanakan rencana yang telah ditetapkan

d. Melakasanakan pengawasan. ${ }^{8}$

Dengan demikian dapat ditarik pemahaman bahwa untuk suskses di dalam perencanaan selain harus memperhatikan unsur-unsur perencanaan tetapi juga harus

7 Didin Kamarudin, dan Imam Machali, Manajemen Pendidikan (Konsep dan Perencanaan Pendidikan, (Yogyakarta: Ar-Ruz Media, 2012), hal. 141

${ }^{8}$ Ibid, hal. 220 
memperhatikan beberapa pertimbangan serta dijalankan berdasarkan fase-fase yang ditetapkan sehingga perencanaan tersebut dapat berjalan efektif dan sesuai dengan tujuan yang direncanakan.

\section{Dasar Fungsi Planning dalam Manajemen Pendidikan Islam}

Islam pada dasarnya masalah planning (perencanaan sempat disinggung dalam beberapa ayat di dalam Al-Qur'an jauh sebelum konsep dan teori manajemen lahir. Hal ini secara eksplisit termuat di dalam beberapa ayat berikut:

$$
\begin{aligned}
& \text { يايهاالذين امنوااتق الله ولتنظرنفس ما قدمت لغد واتقوالله }
\end{aligned}
$$

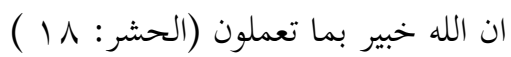

Artinya: Hai orang-orang yang beriman, bertakwalah kepada Allah dan hendaklah Setiap diri memperhatikan apa yang telah diperbuatnya untuk hari esok (akhirat); dan bertakwalah kepada Allah, Sesungguhnya Allah Maha mengetahui apa yang kamu kerjakan. (QS. Al-Hasyr: 59: 18). ${ }^{9}$

Menurut Ibnu Jarir dan Ikrimah dalam Tafsir Jalalain Ayat 18 surat AlHasyar turun berkenaan dengan peristiwa Abdullah bin Salam dan kawan-kawannya dari golongan Yahudi. Mereka berkata "Wahai Rasulullah hari sabtu adalah hari besar kami maka biarkanlah kami merayakannya, dan bahwa Taurat itu kitabullah maka biarkannlah kami membacanya di waktu malam !". Maka turunlah ayat ini sebagai respon atas peristiwa tersebut. ${ }^{10}$

Jika diperhatikan ayat tersebut secara eksplisit menjelaskan bahwa perlunya perencanaan masa depan baik untuk diri sendiri, lembaga, maupun masyarakat mapun pemimpin negara, termasuk di dalamnya pemimpin lembaga pendidikan. ayat tersebut secara tidak langsung juga menjelaskan bahwa dalam

\footnotetext{
${ }^{9}$ Loc.Cit, hal. 564

10 Imam Jalaludin Al-Mahalli, Terjemah
} Tafsir Jalalain, Berikut Azbabun Nuzulnya, (Bandung: Sinar Baru Algesindo, 2004), hal. 2413 perencanaan kita diperintahkan untuk selalu instropeksi dan perbaikan guna mencapai masa depan yang baik. Melihat masa lalu yakni untuk dijadikan pelajaran atau investasi besar bagi masa depan.

Dalam ayat lain Allah menjelaskan bahwa dalam pelaksanaan perencaan pendidikan hendaknya dilakukan secara komperhensif dan mengacu pada tuntutan sosial serta aspek-aspek yang terkandung di dalamnya yaitu dengan memeperhatikan prinsip-prinsip perencanaan. Hal ini sejalan dengan dengan prinsip formulasi pendidikan Islam yang secara universal sebagai keseluruhan aspek manusia yang meliputi agama, masyarakat, dan kehidupan alam semesta, serta muamalah. Berkenaan dengan ini Allah berfirman :

$$
\begin{aligned}
& \text { يايهاالذين امنوا ادخلوا فى السلم كافة ولا تتبعوا خطوت } \\
& \text { الشيطان انه لكم عدومبين (البقرة: م • †) }
\end{aligned}
$$

Artinya: Hai orang-orang yang beriman, masuklah kamu ke dalam Islam keseluruhan, dan janganlah kamu turut langkah-langkah syaitan. Sesungguhnya syaitan itu musuh yang nyata bagimu. (QS. Albaqarah: 2: 208). ${ }^{11}$

Selain perencanan harus dijalankan sesuai dengan prinsip-prinsip perencaan dalam manajemen, dalam mengerjakannya perencanaan juga harus dijalankan secara konsisten, hal ini sejalan dengan firman Allah :

$$
\text { وََاكِيْدُ كَيْدًا (الطارق: } 7 \text { (1) }
$$

Artinya: Dan akupun membuat rencana (pula) dengan sebenar-benarnya. (QS. AtThariq: $86: 16)^{12}$

Menurut Ibnu Katsir dalam tafsir Ibnu Katsir dijelaskan bahwa ayat ini menceritakan tentang kaum kafir yang mendustakan al-Qur'an dan mengahalangi jalan menuju Allah yaitu dengan melakukan 
tipu daya terhadap manusia dengan jalan menyeru kepada umat manusia untuk mengingkari kebenaran Allah. Kemudian turunlah ayat 16 surat at-thariq di atas dimana rencana yang dimaksud dalam ayat di atas adalah bahwa Allah menaguhkan sisksaan kepada orang-orang kafir untuk sementara waktu dengan memberikan kesenangan sesaat di dunia sebelum mereka akan mendapatkan siksa di akhirat nanti. ${ }^{13}$ Realitas yang sama juga dijelaskan di dalam Firman Allah

$$
\text { واملي لهم ان كيدي متين (القلم : 0ـ) }
$$

Artinya: "Dan aku memberi tangguh kepada mereka. Sesungguhnya rencana-Ku Amat tangguh" (QS. Al-Qalam: 68:45)

Kedua ayat tersebut secara tidak langsung menerangkan bahwa Allah mengajarkan manusia untuk membuat strategi perencanaan dalam segenap urusannya dan Allah memerintahkan kita untuk konsisten serta niat yang bersungguhsungguh dalam menyusun perencanaan yang membawa sesuatu pada kemaslahatan. Hal ini juga sejalan dengan pesan yang terkandung di dalam teks hadist yang diriwayatkan oleh Mutafaqun Alaih berikut:

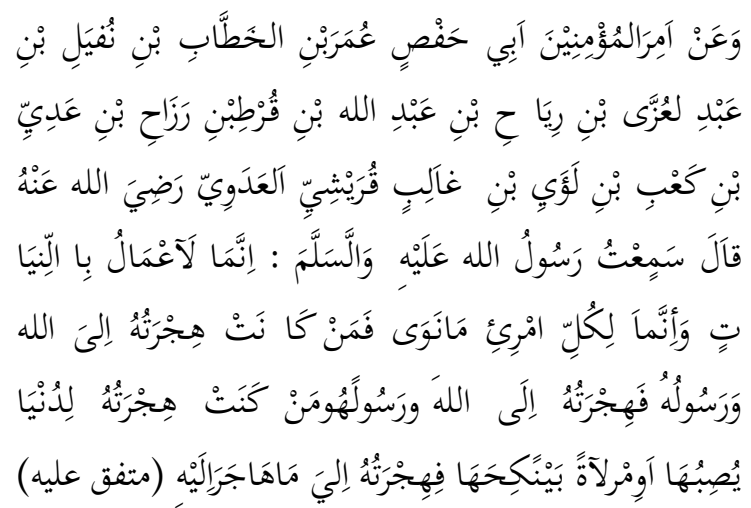
Artinya: Dari Amirul Mukmini Abu Hafsin Umar bin Khatab bin Nufail bin Abdul Uzza bbin Riyah bin Abdullah, bin qurth bin

13 Tedi Ruhiat dan Chandra Kurniawan, Terjemahan Mukhtasar Tafsir Ibnu Katsir, (Jabal: Bandung: 2013), hal. 579

14 Muslich Shabir, Terjemahan Riyadhus Shalihin, Jilid I, (Semarang: PT Karya Toha Putra, 2005), hal. 1
Razah bin Ady bin Kaab bin Luway bin Ghalib Al-Quraisy Al-Adawy ra. berkata Saya mendengar Rasulullah SAW bersabda: Bahwasanya semua amal itu tergantung pada niatnnya. Dan bahwasanya bahwa apa yang diperoleh oleh seseorang adalah sesuai dengan apa yang diniatkannya, barang siapa yang hijrah karena Allah dan Rasulnya dan barang siapa yang hijrah karena mencari dunia atau karena wanita yang dinikahinya maka hijrahnya itu hanya akan memperoleh apa yang diniatkannya dalam hijrahnya itu (Mutafaqun alaih $^{14}$

Hadist di atas menerangkan tentang esensi niat di dalam melakukan suatu pekerjaan, niat sangat menentukan sahnya suatu perbuatan (pekerjaan) dan motivasi akan menentukan diterimanya atau keberhasilan dalam melakukan pekerjaan iru sendiri.15 Demikian pula dalam melakukan perencanaan pendidikan, hendaknya dijalankan dengan kesungguhan dan menjunjung tinggi nilai-nilai kemaslahatan. Adanya dalil hukum di atas menunjukkan bahwa prinsip-prinsip perencanaan dalam manajemen dilandasi oleh idealis normatif yang berlaku dalam tataran hukum agama maupun hukum negara. Dalam konteks hukum negara prinsip-prinsip manajemen pendidikan di dasarkan pada landasan idiil yang sudah sangat kokoh sebagaimana terangkum silasila di dalam pancasila. Dan juga undangundang pendidikan. dengan demikian pada prinsipnya dapat dikemukakan bahwa dalam konsep hukum manajemen Islam maupun konsep hukum manajemen positif mengehendaki bahwa semua bidang pendidikan dapat dikembangkan dan harus memperoleh perlakukan yang porporsional dari para pelaksana pendidikan dan pemerintah sehingga seluruh bidang pendidikan yang dikembangakan dalam

15 Rachmat Syafe'i, Al-Hadis Aqidah, Ahlak, Sosial, dan Hukum, (Bandung: CV Putaka Setia, 2009), hal 62 
masyarakat dapat tumbuh berkembang lebih baik, modern, meningkatkan kecerdasan, keimanan dan ketakwaan sesuai dengan tujuan pendidikan yang dicita-citakan.

\section{Tujuan dan Manfaat fungsi Planning}

Menurut Riduan perencanaan mempunyai tujuan yang penting antara lain:

a. Menjelaskan dan merinci tujuan yang ingin dicapai.

b. Memberikan pegangan dan menetapkan kegiatan-kegiatan yang harus dilakukan untuk untuk mencapai tujuan tersebut.

c. Organisasi memperoleh standar sumber daya terbaik dan mendayagunakan sesuai tugas pokok fungsi yang telah ditetapkan

d. menjadi rujukan anggota organisasi dalam melaksanakan aktivitas yang konsisten prosedur dan tujuan.

e. Memberikan kewenangan dan tanggung jawab bagi seluruh pelaksana.

f. Memonitor dan mengukur berbagai keberhasilan secara intensip sehingga bisa menemukan dan memperbaiki penyimpangan secara dini.

g. Memungkinkan untuk terpeliaranya persesuaian antara kegiatan internal dengan situasi eksternal

h. Menghindari pemborosan. ${ }^{16}$

Perencanaan dipandang penting dan diperlukan bagi suatu organisasi dikarenakan mempunyai manfaat antara lain:

a. Dengan adanya perencanan diharpakan tumbuhnya suatu pengarahan kegiatan. Adanya pedoman bagi pelaksana kegiatan-kegiatan yang ditujukan kepada pencapaian tujuan pembangunan

b. Dengan perencanaan maka dapat dilakukan suatu perkiraan (forcasting) terhadap hal-hal dalam masa pelaksanaan yang akan dilalui. Perkiraan dilakukan mengenai potensipotensi dan prospek-prospek

16 Riduan, Manajemen Pendidikan, (Bandung: Alfa Beta, 2012), hal. 93-94 perkembangan tetapi juga mengenai hambatan-hambatan dan resiko yang mungkin dihadapi. Perencanaan mengusahakan supaya ketidak pastian dapat dibatasi sedini mungkin.

c. Perencanaan memberikan kesempatan untuk memilih berbagai alternatif tentang cara yang terbaik atau kesempatan untuk memilih kombinasi cara yang terbaik

d. Dengan perencanaan dilakukan penyusunan skala prioritas, meilih urutan-urutan dari segi pentingnya suatu tujuan, sasaran, maupun kegiatan usahanya.

e. Dengan adanya rencana maka akan ada suatu alat pengukur atau standar untuk mengadakan pengawasan atau evaluasi kinerja usaha atau organisasi termasuk pendidikan. ${ }^{17}$

\section{Jenis-Jenis Fungsi Planning}

Stoner dan Winkel sebagaimana di kutip HB Siswanto dalam bukunya "Pengantar Manajemen" mengklasifikasikan perencanaan menjadi dua jenis yaitu perencanaan strategis dan perencanaan operasional.

a. Perencanaan Strategis

Perencanaan strategis adalah proses perencanaan jangka panjang yang formal untuk menentukan dan mencapai tujuan organisasi. Perencanaan strategis mempunyai kelemahan dan kelebihan sebagaimana dapat digambarkan dalam bentuk tabel berikut: 
Tabel 1. Perencanaan Strategis

\begin{tabular}{|c|c|}
\hline $\begin{array}{c}\text { Kelebihan Perencanaan } \\
\text { Strategis }\end{array}$ & $\begin{array}{c}\text { Kelemahan } \\
\text { Perencanaan Strategis }\end{array}$ \\
\hline $\begin{array}{l}\text { 1. Manajer dapat } \\
\text { menentukan tujuan } \\
\text { dengan jelas dan } \\
\text { metode } \\
\text { pencapaiannya } \\
\text { dengan organisasinya }\end{array}$ & $\begin{array}{l}\text { 1. Bahaya terciptanya } \\
\text { birokrasi besar para } \\
\text { perencana yang dapat } \\
\text { menghilangkan } \\
\text { hubungan dengan } \\
\text { pelanggan perusahaan }\end{array}$ \\
\hline $\begin{array}{l}\text { 2. Membantu manajer } \\
\text { mengatasi } \\
\text { permasalahan } \\
\text { sebelum muncul dan } \\
\text { memecahkannya } \\
\text { sebelum menjadi } \\
\text { buruk. }\end{array}$ & $\begin{array}{l}\text { 2. terkadang cenderung } \\
\text { membatasi organisasi } \\
\text { pada pilihan yang } \\
\text { rasional dan bebas } \\
\text { resiko. }\end{array}$ \\
\hline $\begin{array}{l}\text { 3. Membantu manajer } \\
\text { mengenal peluang } \\
\text { yang beresiko dan } \\
\text { peluang yang aman, } \\
\text { dan memilih peluang } \\
\text { yang ada }\end{array}$ & $\begin{array}{l}\text { 3. Manajer hanya tahu } \\
\text { mengembangkan } \\
\text { strategi dan sasaran } \\
\text { tersebut yang terus } \\
\text { dapat bertahan dan } \\
\text { analisis perencanaan }\end{array}$ \\
\hline $\begin{array}{l}\text { 4. Mengurangi } \\
\text { kemungkinan deviasi } \\
\text { dankejutan yang tidak } \\
\text { menyenangkan, } \\
\text { karena sasaran, } \\
\text { tujuan, dan strategi } \\
\text { untuk penelitian yang } \\
\text { seksama }\end{array}$ & $\begin{array}{l}\text { 4. Dapat menghindari } \\
\text { peluang menarik yang } \\
\text { melibatkan tingkat } \\
\text { ketidakpastian yang } \\
\text { tinggi atau yang sulit } \\
\text { dianalisis dan } \\
\text { dikomunikasikan. }\end{array}$ \\
\hline $\begin{array}{lr}\text { 5. Manajer } & \text { dapar } \\
\text { memperbesar } & \\
\text { kemungkinan } & \text { untuk } \\
\text { membuat keputusan } \\
\text { yang } & \text { tahan } \\
\text { menghadapi } & \text { ujian } \\
\text { waktu. }{ }^{18} & \\
\end{array}$ & \\
\hline
\end{tabular}

b. Perencanaan Operasional

Perencanaan operasional merupakan merupakan pendeskripsian tentang bagaimana perencanaan strategis dilaksanakan. Perencanaan terdiri atas perencanaan sekali pakai dan perencanaan tetap.

\section{Perencanaan sekali pakai}

Perencanaan sekali pakai adalah arah tindakan yang mungkin tidak akan berpeluang dalam bentuk yang sama yang akan datang. Bentuk perencanaan sekali pakai meliputi;

18 HB. Siswanto, Pengantar Manajemen, (Jakarta: Bumi Aksara, 2011), hal. 48-49 program, proyek, dan anggaran atau budgeting.

2. Perencanaan tetap

Perencanaan tetap adalah pendekatan yang sudah dilakukan untuk menangani situasi yang terjadi berulang dan dapat diperkirakan. Perencanaan tetap ini memberikan kesempatan kepada manajer untuk menghemat waktu dalam perencanaan dan pengambilan keputusan karena situasi serupa yang ditangani dengan cara konsisten yang telah ditentukan sebelumnya. Ada pun bentuk perencanaan tetap meliputi tiga bentuk yaitu: kebijakan (policy), prosedur standar, dan peraturan.

Kebijakan adalah suatu pedoman umum dalam pengambilan keputusan. Ada pun kebijakan diambil berkenaan dengan hal-hal sebagai berikut:

1) Kebijakan tersebut akan meningkatkan efektivitas organisasi

2) Harapan bahwa beberapa aspek organisasi dapat mencerminkan nilai pribadi mereka

3) Perlu menghilangkan adanya kontradiksi atau kekacauan yang terjadi pada tingkatan yang lebih rendah dalam organisasi yang bersangkutan.

Sedangkan prosedur standar adalah suatu pedoman yang memberikan seperangkat petunjuk lebih detil untuk melaksanakan urutan yang sering atau biasa terjadi. Ada pun peraturan itu sendiri mengandung pengertian pernyataan bahwa suatu tindakan harus dilakukan atau tidak boleh dilakukan dalam situasi tertentu dan peraturan juga merupakan rencana tetap yang lebih jelas dan bukan merupakan pedoman pemikiran atau pengambilan keputusan. ${ }^{19}$ Kemudian selain kedua jenis di atas Saefullah

${ }^{19}$ Ibid, hal. 50 
menggolongkan jenis perencanaan sebagai berikut :

Tabel 2. Jenis Perencanaan

\begin{tabular}{|c|c|c|}
\hline No & $\begin{array}{c}\text { Jenis } \\
\text { Perencanaan }\end{array}$ & Pembagian perencanaan \\
\hline \multirow[t]{2}{*}{1} & \multirow[t]{2}{*}{$\begin{array}{l}\text { Perencanaan } \\
\text { berdasarkan } \\
\text { waktunya }\end{array}$} & $\begin{array}{l}\text { 1. Long Range Planning: } \\
\text { Yaitu perencanaan } \\
\text { jangka panjang yang } \\
\text { membutuhkan waktu } \\
\text { yang lama dalam } \\
\text { pelaksanaannya. }\end{array}$ \\
\hline & & $\begin{array}{lr}\text { 2. Intermediate Planning: } \\
\text { Yaitu perencanaan } \\
\text { jangka menengah atau } \\
\text { yang dalam } \\
\text { pelaksanaannya } \\
\text { membutuhkan waktu } \\
\text { pemasangan. } \\
\text { 3. Short range Planning: } \\
\text { Perencanaan jangka } \\
\text { pendek yaitu sebuah } \\
\text { perencanaan } \\
\text { dipersiapkan yang } \\
\text { tergesa-gesa dengan } \\
\text { mendadak dan } \\
\text { pentingnya dan waktu } \\
\text { yang tersedia sangat } \\
\text { sempit. }\end{array}$ \\
\hline \multirow[t]{4}{*}{2} & \multirow{4}{*}{$\begin{array}{l}\text { Perencaan } \\
\text { berdasarkan } \\
\text { wilayah } \\
\text { pelaksanaanya. }\end{array}$} & $\begin{array}{l}\text { a. Rural Planning } \\
\text { (wilayah pedesaa) }\end{array}$ \\
\hline & & $\begin{array}{llr}\text { b. } & \text { City } & \text { Planning } \\
& \text { (perencanaan } \\
& \text { untuatu kota) }\end{array}$ \\
\hline & & $\begin{array}{llr}\text { c. } & \text { Regional Planning } \\
\text { (perencanaan } & \text { tingkat } \\
\text { daerah) } & \\
\end{array}$ \\
\hline & & $\begin{array}{ll}\text { d. National Planning } \\
\text { (perencanaan nasional). }\end{array}$ \\
\hline \multirow[t]{3}{*}{3} & \multirow[t]{3}{*}{$\begin{array}{l}\text { Perencaan } \\
\text { berdasarkan } \\
\text { materinya }\end{array}$} & 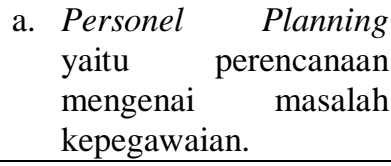 \\
\hline & & \begin{tabular}{lr} 
b. Financial & Planning \\
yaitu & perencanaan \\
mengenai & masalah \\
keuangan & atau \\
permodalan & atau \\
\multicolumn{2}{l}{ anggaran belanja secara } \\
menyeluruh & dan \\
mendetail & \\
\end{tabular} \\
\hline & & $\begin{array}{lrr}\text { c. } & \text { Industrial Planning } \\
& \text { yaitu perencanaan yang } \\
& \text { menyangkut } & \text { kegiatan } \\
& \text { industri } & \text { yang } \\
& \text { direncanakan } & \\
& \text { sedimikian rupa } & \\
\end{array}$ \\
\hline
\end{tabular}

\begin{tabular}{|c|c|c|}
\hline No & $\begin{array}{c}\text { Jenis } \\
\text { Perencanaan }\end{array}$ & Pembagian perencanaan \\
\hline & & 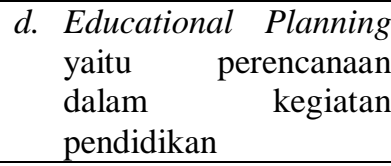 \\
\hline \multirow[t]{3}{*}{4} & $\begin{array}{l}\text { Perencanaan } \\
\text { berdasarkan } \\
\text { jenis umum } \\
\text { dan khusus }\end{array}$ & $\begin{array}{l}\text { a. Genaral Planns } \\
\text { (rencana umum), yaitu } \\
\text { rencana yang dibuat } \\
\text { garis-garis besarnya } \\
\text { dan menyeluruh dari } \\
\text { suatu kegiatan } \\
\text { kerjasama }\end{array}$ \\
\hline & & $\begin{array}{l}\text { b. Spesial Planning } \\
\text { (rencana khusus) yaitu } \\
\text { perencanaan mengenai } \\
\text { masalah yang dibuat } \\
\text { secara mendetail dan } \\
\text { terperinci }\end{array}$ \\
\hline & & $\begin{array}{ll}\text { c. } & \text { Overal Planning yaitu } \\
\text { perencanaan yang } & \text { yan } \\
\text { memberikan } & \text { pola } \\
\text { secara keseluruhan dari } \\
\text { pekerjaan yang harus } \\
\text { dilaksanakan. }\end{array}$ \\
\hline
\end{tabular}

Bertolak dari jenis-jenis perencanaan di atas maka dalam pelaksanannya sebuah perencanaan harus bersifat faktual, rasional, fleksibel, berkesinambungan, dan dialektis. Secara berurutan menurut Hikmat dapat dijelaskan sebagai berikut:

a. Faktual

Yaitu berdasarkan hasil temuan di lapangan , fakta-fakta yang telah dikumpulkan dan dijadikan data serta diolah secara rasional bila perlu dikaji secara ilmiah

b. Rasional

Perencanaan harus bersifat rasional artinya bahwa setiap perencanaan pendidikan harus bersifat positif bagi pengembangan minat dan bakat objek pendidikan serta disesuaikan dengan usia, perekembangan dan pertumbuhan fisik dan psikis anak didik, sehingga hasil yang diperoleh melalui pendidikan tidak menimbulkan dampak negatif dan membahayakan bagi objek pendidikan. 
c. Fleksible

Artinya tidak kaku dan mengikuti perkembangan zaman dan perubahan sesuai dengan situasi dan kondisi sehingga pelaksanaannya tidak terjebak dalam suatu keadaan yang statis

d. Berkesinambungan

Artinya berkelanjutan mengikuti kebutuhan lembaga pendidikan dan masyarakat serta tidak dibatasi oleh situasi dan kondisi. Dan juga harus melahirkan peningkatan dan perbaikan untuk kesempurnaan masa yang akan datang.

e. Dialektis

Yaitu bahwa perencanaan pendidikan sepantasnya mempermudah tercapainya tujuan pendidikan nasional untuk tujuan itulah perencanaan harus dibuat oleh orang-orang yang memahami tujuan pendidikan dengan menggunakan teknik-teknik perencanaan yang baik. ${ }^{21}$

\section{Model, Prinsip, dan Proses Planning}

Terdapat beberapa model dalam perencanaan antara lain:

a. Model perencanaan komprehensif

Model ini digunakan untuk menganalisis perubahan-perubahan dalam sistem pendidikan secara keseluruhan. Disamping itu model ini juga berfungsi sebagai suatu patokan dalam menjabarkan rencana-rencana yang lebih spesifik ke arah tujuan-tujuan yang lebih luas.

b. Model terget setting

Model ini diperlukan dalam upaya melaksanakan proyeksi maupun memperkirakan tingkat perkembangan kurun waktu tertentu. Dalam persiapannya diperlukan model-model untuk menganalisis demografis dan proyeksi penduduk, model untuk memproyeksi enrolmen (jumlah siswa terdaftar) sekolah, dan model untuk memproyeksikan kebutuhan tenaga kerja.

\section{c. Model Casting}

Model ini sering digunakan untuk menganalisis proyek-proyek dalam kriteria efesien dan efektifitas ekonomis. Dengan model ini dapat diketahui proyek yang paling fleksibel dan memberikan sesuatu perbandingan yang paling baik diantara proyek-proyek yang menjadi alternatif penanggulangan masalah yang dihadapi. Penggunaan model ini dalam pendidikan karena adanya pandangan bahwa pendidikan tidak terlepas dari masalah biaya.

\section{d. Model PPBS (Planning,}

\section{Programmming, Budgeting System)}

PPBS merupakan merupakan suatu pendekatan yang sistemik yang berusaha untuk menetapkan tujuan, mengembangkan program-program untuk dicapai, menemukan besarnya biaya, dan alternatif menggunakan proses penganggaran yang merefleksikan kegiatan program jangka panjang.

Pengertian tersebut secara tidak langsung menjelaskan beberapa sifat esensial dari sistem ini yang meliputi:

a. Merinci secara cermat dan menganalisis secara sistemik terhadap tujuan yang ingin dicapai.

b. Mencari alternatif-alternatif yang relevan, cara yang berbeda-beda untuk mencapai tujuan

c. Menggambarkan biaya total dari setiap alternatif baik langsung maupun tidak langsung, biaya yang telah lewat maupun biaya yang akan datang, baik biaya yang berupa uang maupun biaya yang tidak berupa uang. ${ }^{22}$

Perencanaan yang efektif hanya akan terlaksana jika setiap dari anggota dalam organisasi mempunyai kesadaran yang tinggi tentang pentingnya perencanaan dalam membangun masa depan. Terdapat tiga sikap yang menjadi prinsip mental setiap anggota atau individu anggota organisasi pendidikan dalam

\footnotetext{
${ }^{21}$ Hikmat, Loc. Cit, hal. 114
}

${ }^{22}$ Loc. Cit, hal. 177-178 
membangun perencanaan yang efektif yaitu:

a. Kesadaran diri (self awareness) Artinya hanya diri kitalah yang menjadi penentu masa depan kita, (we are the creator of our own future)

b. Responsibility (Tanggung jawab)

Dalam pengertian mempunyai tanggung jawab untu menuliskan gambaran masa depan yang dikehendaki dan langkahlangkah yang akan ditempuh untuk mewujudkannya.

c. Integrity (integritas)

Adalah kemampuan seseorang untuk mewujudkan apa yang telah direncanakan, integritas menuntut kewajiban bahwa kita lah yang berkewajiban untuk mewujudkan apa yang telah kita rencanakan. ${ }^{23}$

Menurut Broocover sebagaimana dikutip Syaiful Sagala bahwa dalam proses untuk merencanakan sutu perencanaan harus memberikan kesempatan yang cukup untuk berdiskusi "brainstroming", mengutarakan perasaan, pendapat dan sikap, menyiapkan informasi dan data, mengidentifikasi kebutuhan dan harapan dan memecahkan selisih pendapat. ${ }^{24} \mathrm{Hal}$ yang demikian untuk memperoleh masukan yang berharga selama proses perencanaan berlangsung.

Kemudian perencanaan sebagai proses mempunyai tahap-tahap sebagai berikut:

a. Perumusan tujuan baik yang bersifat umum maupun khusus

b. Perumusan kebijakan yaitu bagaiman mencapai tujuan yang telh ditentukan sebelumnya dalam bentuk tindakantindakan yang terkoordinir, terarah, dan terkontrol

c. Perumusan prosedur dengan menentukan batas kewenangan dari masing-masing komponen sumber daya sehingga pelaksanaan kegiatan tidak tumpang tindih. d. Perencanaan merumuskan dan menentukan standar hasil yang akan diperoleh serta skala mengukur kemajuan melalui pelaksanan aktivitas pada waktu yang telah ditentukan baik yang sifatnya kuantitatif maupun kualitatif

e. Perencanaan yang masuk kategori yang sempurna adalah bersifat menyeluruh dengan memperhitungkan berbagai aspek yang melingkupinya. ${ }^{25}$

Dengan memperhatikan proses tersebut maka dapat diketahui bahwa dalam perencanaan tidak ada yang bersifat final karena prosesnya selalu berkesinambungan dan terbuka untuk dilakukan perbaikan.

\section{PEMBAHASAN}

Setiap kepala sekolah tidak hanya memiliki tanggungjawab untuk membuat perencanaan dan membagi tugas kepada semua guru tetapi harus mampu menjadi pendorong dan motivator bagi bawahannya. Sehingga tercipta kondisi belajar yang efektif dan guru yang efektif dalam menjalankan tugasnya. Kepala sekolah sangat dituntut untuk mempengaruhi dan menggerakkan guru sesuai dengan mekanisme dan aturan yang berlaku tanpa ada intimidasi ataupun tekanan sehingga mereka dapat melaksanakan tugas-tugasnya secara profesional dan memilki kinerja yang tinggi.

Kepala sekolah sebagai perencana di sekolah memiliki kemampuan perecanaan yang baik dan dapat mengkoordinasikannya dengan mitra kerja, menggerakkan dan menyelerasikan semua sumber daya pendidikan yang tersedia di sekolah. Fungsi perencanaan kepala sekolah merupakan salah satu faktor yang dapat mendorong sekolah untuk dapat mewujudkan visi, misi dan tujuan sekolah melalui program-program yang dilaksanakan secara terencana dan bertahap. Oleh karena itu, kepala sekolah dituntut mempunyai kemampuan

\footnotetext{
${ }^{25}$ Ibid, hal. 61
}

${ }^{23}$ Ibid, hal, 150

${ }^{24}$ Syiful Sagala, Loc.Cit, hal. 59-60

\section{Ibid, hal. 61}


menajemen dan kepemimpinan yang memadai agar mampu mengambil inisiatif dan prakarsa untuk meningkatkan kinerja gurudi sekolah.

Tetapi, jika kepala sekolah tidak memiliki kemampuan dan pengetahuan manajemen dibidang perencanaan maka visi dan misi sekolah tidak dapat terwujud dan sumber daya sekolah tidak dapat dimanfaatkan dengan tepat. Berikut hasil wawancara peneliti dengan kepala sekolah: "sebagai kepala sekolah saya akui belum sepenuhnya memiliki dan merencanakan semua pekerjaan yang behubungan dengan peningkatan kinerja guru dan karyawan, disamping banyak keterbatasan yang saya miliki apalagi dari sisi pengalaman manajerial yang sangat kurang saya miliki."26

Fungsi planning kepala sekolah harus mampu merencanakan setiap tindakan yang akan diterapkan di sekolah, sebaiknya setiap kegiatan yang akan dilaksanakan tidak boleh terlepas dari proses perencanaan, sebab semua kegiatan sekolah bisa sukses karena pada umumnya direncanakan dengan matang. Kepala sekolah yang di bantu guru dan karyawan selalu mengadakan musyawarah bersama untuk memperbaiki kelemahan kelemahan yang mungkin terjadi di sekolah dalam proses belajar mengajar.

kepala sekolah yang belum optimal menjalankan perannya sebagai perencana dan pimpinan lembaga, terbukti kurangnya mengawasi perencanaan aktivitas guru dan karyawan yang dapat meningkatkan kinerja mereka masing-masing. Sebaiknya sebagai seorang kepala sekolah harus dapat dan mampu mengontrol aktivitas guru dan karyawan baik dalam keadaan dinas maupun diluar dinas, adapun tujuannya adalah supaya mereka dapat memiliki kinerja yang tinggi dalam melaksanakan tugas mereka masing-masing.

Pada dasarnya baik buruknya suatu sekolah akan sangat ditentukan oleh kinerja guru dan karyawan sekolahnya. Kinerja guru dan karyawan merupakan fungsi operasional manajemen kepala sekolah terhadap sumber daya manusia, karena semakin matang program perencanaan guru dan karyawan semakin tinggi pula kinerja yang dapat dicapainya di sebuah lembaga pendidikan. Tanpa perencanaan yang baik bagi seluruh guru, sulit bagi lembaga pendidikan atau sekolah mencapai hasil yang optimal. Perencanaan dapat terealisasi dalam bentuk kesadaran dan kesediaan seseorang guru untuk mentaati semua peraturan sekolah dan norma-norma sosial atau budaya sekolah yang berlaku. Sikap ini diwujudkan oleh guru dan karyawan secara sukarela untuk menaati peraturan dan sadar akan tugas dan tanggung jawab yangb telah direncanakan sebelumnya.

Jika kepala sekolah menginginkan mutu pendidikan di sekolahnya maka ia harus memperbaiki kinerja guru dan para sumber daya manusia lainnya di sekolah tersebut. Guru dan karyawan sebagai pelaksana fungsi planning sangat dipengaruhi oleh sarana dan prasarana sekolah, oleh karena itu kepala sekolah harus melakukan berbagai usaha untuk meningkatkan kinerja guru dan karyawan dengan peningkatan sarana prasarana pendidikan yang dapat menunjang kinerja guru dan karyawan.

Fungsi planning kepala sekolah sebagai menjadi sosok yang dicontoh oleh semua anggota sekolah. Sehingga ketika kepala sekolah kurang efektif merencanakan tugas maka seluruh anggota juga akan melakukan hal yang sama. Jadi kendala penerapan fungsi planning untu meningkatkan kinerja guru dan karyawan yaitu kurang efektifnya perecanaan yang dibuat kepala sekolah sehingga kinerja guru dan karyawan kurang meningkat.

\footnotetext{
${ }^{26}$ Wawancara, tanggal 1 November 2017
} 


\section{PENUTUP}

Dari hasil pembahasan dan uraian yang telah disebutkan, maka dapat diambil kesimpulan dan saran sebagai berikut:

a. Pentingnya menerapkan dan menjalankan fungsi planning sehingga guru dan karyawan yang memiliki kinerja yang baik dalam menjalankan tuigasnya masing-masing.

b. Kepada kepala sekolah penulis sarankan agar dapat menjalankan dan menerapkan fungsi planning secara profesional dan selalu memberikan wawasan baru dan inovatif, kreatif kepada para guru dan karyawan semoga mereka menyadari akan pentingnya kinerja dalam profesionalitas dalam bekerja.

c. Kepada para kepala dinas dan pengawas agar selalu mengadakan supervisi, monitoring dan evaluasi langsung ke sekolah semoga kepala sekolah selalu menjalankan fungsi planningnya sebagai kepala sekolah dan para guru dapat meningkatkan kinerja secara profesional.

\section{DAFTAR PUSTAKA}

Ahmad Kamaludin, Udang. dan Alfan, Muhammad. 2010. "Etika Manajemen Islam". (Bandung: Pustaka Setia).

Ari Kunto, Suharsini . 2005. "Prosedur Penelitian”. (Jakarta: Rineka Cipta)

Baharudin dan Umiarso. 2013. "Kepemimpinan Pendidikan Islam Teori dan Praktik”. (Yogyakarta: Ar-Ruzmedia)

Departemen Agama. 2007. "Al-Qur'an dan Terjemah". (Bandung: CV Diponegoro).

Danim, Sudarwan. 2006. "Visi Baru Manajemen Sekolah, Dari Unit Birokrasi ke Lembaga Akademik". (Jakarta: Bumi Aksara).

Darmadi, Hamid. 2013. "Dimensi-Dimensi Metodologi Penelitian Pendidikan dan Sosial Konsep Dasar
Impelementasi”. (Bandung: Alfa Beta)

Hikmat. 2011. Manajemen Pendidikan. Bandung: Pustaka setia.

Daryanto, M. 2012. "Administrasi dan Manajemen Sekolah". (Jakarta: Rineka Cipta).

Hadis, Abdul. dan Nurhayati. 2012. "Manajemen Pendidikan". (Bandung: Alfa Beta).

Hidayat, Ara. 2012. "Pengelolaan Manajemen Pendidikan". (Yogyakarta: Kaukaba).

Hadi, Amirul. 2009. dan Haryono, "Metodologi Penelitian Pendidikan",. (Bandung: Pustaka Setia)

Iskandar, 2010. "Metodologi Penelitian Pendidikan dan Sosial (Kualitatif dan Kuantitatif)”. (Jakarta: Gaung Persada Press).

Karwati, Eusi. dan Juni Priansa, Doni. 2013. "Kinerja dan Profesionalisme Kepala Sekolah”. (Bandung: Alfa Beta)

Kamarudin, Didin. dan Machali, Imam. 2012. "Manajemen Pendidikan (Konsep dan Perencanaan Pendidikan". (Yogyakarta: Ar-Ruz Media)

Muahaimin, dkk. 2013. "Manajemen Pendidikan, Aplikasi dalam Penyusunan Rencana Pengembangan Sekolah / Sekolah". (Jakarta: Prenada Media Group).

Muhammad. 2011. "Metodologi Penelitian”. (Jakarta: Rajawali Press).

Mukhtar. 2013. "Metode Praktis Penelitian Deskriptif Kualitatif”. (Jakarta: Gaung Press Group)

Riduan. 2012. “Manajemen Pendidikan”. (Bandung: Alfa Beta) 
Ridwan, Ahmad. 2014. "Karakteristik Tim, Pengetahuan Manajemen, Etika Kerja dan Kinerja Katua Program Studi Perguruan TinggI Islam, ( Yogyakarta: Insan Madani)

Ruhiat, Tedi. dan Kurniawan, Chandra. 2013. "Terjemahan Mukhtasar Tafsir Ibnu Katsir". Bandung: Jabal.

Saefullah. 2012. "Manajemen Pendidikan Islam". (Bandung: Pustaka setia).

Siswanto, HB. 2011. "Pengantar Manajemen". (Jakarta: Bumi Aksara).

Syaefudin Saud, Udin. dan Makmun, Abin Syamsudi. 2005. "Perencanaan Pendidikan Suatu Pendekatan Komperehendif". Bandung: PT Rosda Karya).

Sagala, Syaiful. 2011. "Kemampuan Profesional Guru dan Tenaga
Kependidikan”. (Bandung: Alfa Beta)..

Shabir, Muslich. 2005. "Terjemahan Riyadhus Shalihin Jilid I'. (Semarang: PT Karya Toha Putra)

Suprapto. 2013. "Metodologi Ilmu Pendidikan dan ilmu-ilmu Pengetahuan Sosial (Penelitian Kualitatif dan Kuantitatif". (Jakarta: CAPS (Centre For Academik Publishing Service).

Stronge, James H. 2013. “Kualitas Kepala Sekolah Yang Efektif”. (Jakarta: PT Indeks)

Subari, Tata. 2006. "Sistem Informasi Manajemen”. (Yogyakarta: CV Andi Offset).

Syafe'i, Rachmat. 2009. "Al-Hadis Aqidah, Ahlak, Sosial, dan Hukum". (Bandung: CV Putaka Setia) 